\title{
ON BILINGUALISM IN A (MONOLINGUAL?) ENGLISH CLASSROOM ENVIRONMENT - THE CHALLENGES FOR POLISH-ENGLISH BILINGUAL CHILDREN, THEIR PARENTS AND SCHOOLS ${ }^{1}$
}

\begin{abstract}
Summary. Poland is one of the biggest countries among the accession states, and between 2004 and 2008, Poles constituted the largest migrant group, and currently, Polish is the second most widely spoken language in England and Wales, with more than half a million people speaking Polish as their first language. It is predicted that the number of Polish-English bilingual children in the UK will continue growing; therefore, the needs of these children need to be studied and addressed. This article will provide some background information on the nature of Polish migration and its key features, as this knowledge may facilitate better understanding of the Polish-English bilingual pupils within the English system of education. It will consider some of the challenges for Polish parents, their bilingual children and the teachers of these children within English monolingual curriculum and assessment which seems to be largely outdated and inappropriate for an increasingly diverse population. Three in-depth cases studies will be presented to illuminate specific issues and challenges, highlighting how myths about bilingualism are still alive and at play and how they can impact on the children psycho-social development and behaviour as well as put strain on the relationship between schools and parents. Some tentative recommendations will be made and future research directions will be discussed.
\end{abstract}

Keywords: Polish-English bilinguals, education, language assessment, language and psycho-social development

\section{Introduction}

Although children who use a language other than English are not a minority population (especially in urban areas) in the UK, we argue that English classrooms remain largely monolingual and (to a lesser extent) also monocultural. Monolingualism is still perceived as the norm, and there seems to

\footnotetext{
${ }^{1}$ This article is based on the conference presentation (under the same title) given at the Multilingual Families conference on 5th November 2014 in Lodz, Poland.
} 
be an expectation of children to acquire English as fast as possible and assimilate into the English system of education. The underlying assumption for this seems to be that 'other languages and cultures interfere with successful learning of [English] and with achievement in the curriculum' (Levine, 1990, p. 1); and therefore, learners should focus mainly on English. Sales, Ryan, Lopez Rodriguez and D'Angelo's (2008) report on Polish pupils in London schools provides revealing evidence of such attitudes among educators. For instance, the teacher quoted below not only expects the child to make an effort to speak English, but also seems to feel that the Polish mother should speak English to her child in their Polish household:

I said I was concerned about A that she was not going to get her level 4 because she is not accessing the curriculum because she is not accessing the language. There was a stubbornness about it. So I said to the mum "do you speak any English at home ever" and that was not happening' (Sales, 2008, p. 20)

Even though such views have been heavily challenged in the literature (e.g., Baker, 2007; Bialystok, 2001; Levine, 1990), and, as Safford and Drury (2012) explain, the move from segregation to inclusion of bilingual children was enacted as a matter of civil and educational rights, these efforts have been:

... undermined by national education policy which has eroded language support and imposed highly prescriptive content and pedagogy. Bilingual learners have come to be 'included' in a strongly centralised, monolingual national curriculum and assessment system where, for instance, all children are taught a specific phonics method for the teaching of early reading (Department for Children, Schools and Families [DCSF], 2007) and are given a phonics test at age five or six (DfE, 2010; Richardson, 2011). There is little space for schools to respond to local language and cultural contexts (Leung \& Creese 2008) and therefore little space for teaching or assessment practices that take 
account of bilingual children's learning paths; for instance, the national Early Years Foundation Stage (EYFS) Curriculum sets pre-specified learning targets for children from birth to age five and attaches age phases to descriptors of language development which are native English speaker developmental norms, emphasising that at age five, children should be 'school ready' by reaching a good standard of English language. ... Large numbers of bilingual children therefore enter mainstream education pre-labelled as underachievers in relation to mother tongue English norms." (Safford \& Drury 2012, p. 72-73).

This centralised, monolingual curriculum and assessment seems to be largely outdated and inappropriate for an increasingly diverse population, especially in classrooms where English native speakers may indeed be in a minority. Eversley et al. (2010) reported that $41 \%$ of state school children in London use another language in addition to English (with Somali, Tamil, Polish and Albanian being the most widely used languages). According to Safford and Drury (2012), 12\% of all pupils can be identified as bilingual; this estimate rises to $50 \%$ in urban areas, such as inner London (with some London primary schools having as much as an $80 \%$ bilingual pupil population). Moreover, they point out that this population in itself is very diverse and encompasses new arrivals from the European Union (EU), refugees and asylum seekers, as well as children from long-settled minority ethnic communities.

\section{Background to the study - Polish migration to the UK}

Since 2004, there has been a rapid increase in Polish migration to the UK - as Sales et al. (2008) state, this emigration wave was "substantial, and largely unplanned", with thousands of Polish children entering British schools, "often with little knowledge of English or of the environment into which they have been thrust" (p. 4). Poland is one of the biggest countries among the accession states, 
and between 2004 and 2008, Poles constituted the largest migrant group (Home Office, 2006). Currently, Polish is the second most widely spoken language in England and Wales (Booth, 2013; Rawlinson, 2013) with more than half a million people speaking Polish as their first language. This is a dramatic change, as back in 2001, Polish was not even in the UK's top 12 languages (Ethnologue, in 2001, cited in Booth, 2013, para 9). Although there is an indication that due to the improvement in the Polish economy, the return migration is increasing (causing also issues in Polish schools, to which immigrant children who have been partly educated in the UK return), substantial numbers of Poles plan to remain in the UK for the long term, and new immigrants continue to arrive (Pollard, Latorre, \& Sriskandarajah, 2008). Indeed, as Ryan et al. (2009) point out, children's education can become an important factor in deciding whether to stay in the UK or return to Poland. This is because parents do not want to disrupt their children's continuity of education once they have started in one system.

Sales et al. (2008) highlighted six key features of Polish migration that have significant implications for children's experiences and challenges as they settle in in British schools. Firstly, the speed of migration has been unprecedented, with some schools going from no Polish pupils to several dozen within a space of two to three years. Moreover, migration has become a normal part of life for many Polish people, and Sales et al. (2008) suggest that this has led to them make little preparation for a move. Therefore, they may often be unfamiliar with the local language and the host country's system of education, and therefore, "children may be placed into an unfamiliar environment, which they, and their parents, find hard to understand in early stages" (p. 6).

Secondly, literature also points to the often temporary and circular form of migration displayed by the Poles (e.g., "commuter migration," (Morokvasic, 2004)), which takes the form of retaining "a stake in Polish society and the option to return," and which, in turn, reduces "motivation to learn English and to integrate in Britain" (Sales et al., 2008, p. 7).

Thirdly, due to their EU status, Polish migrants have developed "a sense of entitlement" in Britain (that perhaps migrants from non-EU countries do not display) and high expectations of services, including education. 
ON BILINGUALISM IN A (MONOLINGUAL?) ENGLISH CLASSROOM ENVIRONMENT - THE CHALLENGES FOR POLISH-ENGLISH BILINGUAL

CHILDREN, THEIR PARENTS AND SCHOOLS

Fourthly, Poles are reported to lack familiarity with diversity and multiculturalism, as contemporary Polish society is predominantly white $(98 \%)$ and Catholic. Therefore, children joining British schools may have limited knowledge and experience in dealing with other cultural and religious groups. This can lead to misunderstandings and xenophobic behaviour.

Fifthly, some parents' economic situations (low-status employment, high levels of deskilling, long hours, shift work, insecure contracts, etc.) often impact their ability to become involved in their children's education, and sometimes to provide an appropriate environment for their children to study.

Lastly, there is also an issue of geographical dispersion, with Polish migrants often working in agriculture and services and their children attending schools in areas that lack diversity, where Polish pupils become more visible as 'foreign' and may be subject to racial abuse in schools that have little experience in dealing with such matters. We will refer to some of these issues in our case studies' descriptions below.

However, we would also like to draw readers' attention to the fact that the characteristics described above give an illusion of uniformity of the Polish population in the UK. This is certainly not the case, as the demographic picture is much more complex, with many multicultural families (e.g., where only one parent is Polish), families with higher SES, and bilingual children born in the UK (or brought early on in life), for whom actually English (not Polish) is a dominant language.

The factors and challenges described above, together with the fact that Polish children constitute one of the biggest minorities in the UK education system, prompts many researchers to look into their specific positioning and the issues they face in schools. The primary focus of education policies is that English-only instruction is the best way to improve English-language-learner students' communication with their peers and teachers, and many sources report teachers' expectation and emphasis on gaining English and assimilation to the system and the environment. This, from our perspective, is a worrying phenomenon. While learning English and understanding the local system is, of 
course, important, keeping native language and traditions is a well-known psychologically protective factor (Winsler et al., 2014). As children become more integrated into English culture, they seem to lose the protection and caring features of their home culture. In addition, it has been reported that they also become increasingly reluctant to speak their family's language and unable to preserve their parents' linguistic heritage, which is not only detrimental to academic outcomes but also to cognitive flexibility and abstract thinking (Portes \& Hao, 1998).

Given that Polish migration seems to be more temporary (with many families keeping their options of returning to Poland open), retaining ones' own language and tradition may be particularly important. However, as indicated in the introduction, addressing the needs of bilingual children is not a priority in most British schools. Safford and Drury (2012) highlight that there are no dedicated funds to support bilingual learners in schools in England. Schools can apply for a 'pupil premium' based on economic deprivation, with the sole qualifying measure being a child's eligibility for free school meals, but this criteria does not apply to many children. Moreover, bilingual children are measured against monolingual native English speaker norms and can be perceived as underachievers from the very beginning, as we document in our case studies below. Receiving what is termed "failure feedback," a child may experience reduced confidence in his or her abilities or future success and a negative educational trajectory (Eccles, 1999). The negative social comparison and the "failure feedback" received in schools have distinct implications for pupils who see their own cultural identity differently from their peers, which can lead to an increased probability of later dropout and delinquency (Dodge, Pettit, \& Bates, 1994; Hamre \& Pianta, 2001; Parker \& Asher, 1987; Rose, Rose, \& Feldman, 1989; Wehby, Dodge, \& Valente, 1993). This problem is of particular significance for young children, given the plasticity of their behavioural and emotional well-being during the early school years (Alexander \& Entwisle, 1993; La Paro \& Pianta, 2000; Rumbaut, 1994; Saft \& Pianta, 2001).

This paper reports on a pilot investigation into the relationship between bilingual (Polish-English) children's language status and their behavioural and 
social wellbeing during their school years. In this study, we wanted to explore the issues that Polish-English bilinguals faced in the English system of education in order to be able to frame our future examination of how being bilingual may shape children's long-term emotional well-being and how bilingualism may be a strength that policymakers can draw upon in their efforts to promote children's success in school.

\section{Aims of the study}

The study was conducted within an area of dense Polish population in Bedfordshire, England, to which one of the authors readily had access. The aim was to investigate the association between oral and written communication and its impact on how children were being perceived in schools. We also aimed to gather data that could aid our understanding of the relationship between the language status of children and their behavioural and emotional well-being. Finally, a further aim was to establish a community project and begin building a parent/child database for recruitment for present and future studies. In this paper, we report on three case studies to illuminate the discussion on issues faced by Polish-English bilinguals in the English system of education.

\section{Methodology}

This study employed a multi-method approach. The data was collected from three sources: parents, teachers and children. The parents' and teachers' opinions about the children were surveyed via questionnaires that were specifically constructed for the purpose of this study based on available measures widely used with good reliability and validity, such as McCulloch, Wiggins \& Sachdev's (2000) scale of behaviour problems. The teacher questionnaire asked about the child's level of English upon entry to school, as well as the current level and any additional support received. It also asked about 
academic performance and (compared to typical pupils of the same age) the child's effort, behaviour (in general), how much s/he is learning and how happy s/he is, and any concerns about the child, as well as the child's best points. Finally, it also asked the teacher to judge the child on behaviour problems that many children have - this included external (the frequency of arguing, fighting, getting angry, acting impulsively, and disturbing ongoing activities) and internal (the apparent presence of anxiety, loneliness, low self-esteem, and sadness) behaviours.

The parent questionnaire also asked about the child's level of English at the point of entry to school as well as current level and any additional support received, academic performance, any concerns and strengths as well as external and internal behaviour problems. Additionally, it surveyed the home language use (dominant languages of all family members and the patterns of languages spoken, e.g. the frequency of use of the child's mother tongue and other language/s) with each family member. Although not directly asked about their experiences with schools, parents frequently volunteered information about their interaction with schools and concerns they had about it.

The children's language was assessed using the Oral and Written Language Scales (OWLS-II) test. The OWLS-II is a comprehensive assessment which provides a complete and integrated picture of oral and written skills across a wide age range (up to 21 years). It provides scale scores as age- and gradebased standard scores, test-age equivalents, grade equivalents, percentile ranks and descriptive categories plus five composites: Oral Language, Written Language, Receptive Language, Expressive Language, and Overall Language.

\section{Ethics}

The research, ethically approved by the Psychology Department Ethics Committee, adhered to the British Psychological Society Ethical Code of Conduct. The schools, parents and children received a comprehensive information pack. Consent forms were signed the by parents and teachers, and assent forms were obtained from the children participating in this pilot study. In order to protect 
the family's identities, we use pseudonyms and keep other information to the minimum.

All parents and children were debriefed after the study and offered guidance on where they can find more information about dual language learning and education. Once the principal investigator calculated the scores, these were relayed to the parents and children and thoroughly explained. The scores were not reported back to the schools, but the parents and children could use them as a basis for discussions with teachers, should they wish to. Some parents welcomed this opportunity, and those who used it reported that it was useful. In three cases, the parents reported that they felt a slight change in the schools' attitude towards their offspring and that they felt a bit more understood. In a few cases, the parents asked for further guidance and recommendations, and although this was not included in the research plan, the principal investigator felt obliged, seeing this as her social responsibility and therefore provided some careful recommendations. In one case, the head teacher contacted the researchers to thank them for the information sharing and recommendations provided, as can be seen in the quote below:

Mrs. Jankowska,

Many thanks for your information sharing and, in particular, your recommendations for $\mathrm{X}^{\prime} \mathrm{s}$ individual support plan.

I will discuss these with our SENCo, Mrs. ... in order to target the support that is going to have the most impact bearing in mind the complexity of $X^{\prime}$ 's needs as you point out. It is clear that we need to draw on multi agency support to help us understand his needs further and to ensure that the individual support plan is appropriate.

Thanks once again for sharing this information.

Kindest regards (head teacher, case 3 ). 


\section{Sample}

This small pilot study included 10 case studies. Each case study was based on the information provided by parents (parent questionnaire), teachers (teacher questionnaire) and assessment of the children (on comprehensive Oral and Written Scales - OWLS-II). All children were Polish-English bilinguals, but their language status was varied, as their family backgrounds differed (some children came from Polish families and some had dual heritage, some were born in Poland and some were born in England, some spoke only one language early in life - usually Polish, while others used two languages from birth). Such diversity in the sample was intentional, as we wanted to explore whether language status and socio-cultural context influenced the teachers' perceptions of the children and had an impact on their school experiences.

\section{Results - Case studies}

\section{Case Study 1 - Kamila}

The child in the centre of this case is a teenage girl (13.7 years at the time of assessment) who comes from a Polish migrant family that had arrived in the UK approximately a year prior to the assessment. Kamila had studied English (as all Polish children do) in her previous schools in Poland. However, English was learned as a second language and not to a level that would be sufficient to fluently communicate in an English school. Therefore, she is a typical sequential bilingual with a strong dominance of a native language (Polish). The family communicates in Polish and Kamila has a younger sibling who began school in reception with no English. The parents reported that their daughter had been a high achiever in Polish schools (particularly talented in creative writing, but achieving in all areas of the curriculum), and they continued to have high expectations of her, believing she could continue achieving at the same level in England. 
ON BILINGUALISM IN A (MONOLINGUAL?) ENGLISH CLASSROOM ENVIRONMENT - THE CHALLENGES FOR POLISH-ENGLISH BILINGUAL CHILDREN, THEIR PARENTS AND SCHOOLS

Kamila's mother expressed her strong disappointment with the schooling system in England and felt that her daughter's abilities were not recognised and, consequently, Kamila was not challenged beyond her level. Her mother felt that her daughter could do so much better, but the teachers "are not bothered" ("it's not quite good, because she is not encouraged to do more. Her development and progress are not good enough. She could do so much more"). She gave examples of Kamila getting tasks and homework which were very simple, much below her ability levels and below what she was used to doing back in Poland; and she pointed out that Kamila was becoming demotivated by this. Her mother was aware of Kamila's EAL status (Kamila was getting one hour per week of additional support at school) and explained that, in her perception, because of Kamila's developing English, she was being treated as not cognitively able. The mother was also concerned with her daughter's marked shyness and progressively worrying withdrawal. She reported that her daughter had 1 friend (Polish) and "can't speak with other children." She also explained that her child did not eat lunch at school at all and went all day hungry. This is because the girl felt intimidated and did not want to eat in the big hall, and the head teacher "forbid [her] to eat lunch during language club" (or at any other time/place). The mother was disappointed with the school's attitude - the lack of acknowledgement of these psychological problems, and consequently, the absence of any interventions.

The data reported by the teacher was scarce and evidenced rather shallow knowledge of Kamila and her specific issues. The teacher had "no concerns" and believed that the girl "worked really hard and was very keen to improve English" - these were the teacher's only comments. In terms of her academic performance, Kamila was judged to be "average" in most subjects (although the data are incomplete) and "above average" in numeracy. Compared to typical pupils of the same age (on the scale ranging from much less/ somewhat less/ slightly less/ about average/ slightly more/ somewhat more to much more), the teacher felt that Kamila was: working somewhat more than others, behaving much better, learning much more and about average in 
terms of happiness. On the scale that describes behaviour problems, the teacher marked 'not true' for each of twenty-six items. On the same scale, the mother reported several worrying behaviours, including: being rather high strung, nervous or tense; too fearful or anxious; arguing too much; being disobedient; not being sorry after she misbehaves; having trouble getting along with others; being impulsive and acting without thinking; being restless and overly active; being stubborn, sullen and irritable; having a very strong temper and losing it easily; but also being withdrawn from contact with others. The mother also felt that Kamila sometimes feels worthless or inferior, cheats or tells lies, is unhappy, sad or depressed, cries too much, clings to adults and is too dependent on others, demands attention and is not liked by other children.

From conversations with this family, a clearer picture started forming. It appeared that Kamila was withdrawn, quiet and almost "invisible" at school, and hence, her problems and inhibitions were not being noticed. At home, however, she vented her anger and disappointment, frequently causing conflicts and expressing her wish to return to Poland. Her parents felt despair, not knowing how to help Kamila.

Assessment conducted with the use of OWLS-II further illuminated Kamila's situation. We present and discuss the main scores below, in Table 1.

Table 1

Case 1: Standard scores

\begin{tabular}{|c|c|c|c|}
\hline $\begin{array}{c}\text { Listening } \\
\text { comprehension }\end{array}$ & Oral expression & $\begin{array}{c}\text { Reading } \\
\text { comprehension }\end{array}$ & $\begin{array}{c}\text { Written } \\
\text { expression }\end{array}$ \\
\hline $\mathbf{9 2}$ & $\mathbf{7 9}$ & $\mathbf{9 9}$ & \multicolumn{1}{|c|}{$\mathbf{3 7}$} \\
\hline Average & Below average & Average & $\begin{array}{l}\text { Very superior (less } \\
\text { than 2.2\% of pupils } \\
\text { this age achieve } \\
\text { such a score) }\end{array}$ \\
\hline
\end{tabular}


ON BILINGUALISM IN A (MONOLINGUAL?) ENGLISH CLASSROOM ENVIRONMENT - THE CHALLENGES FOR POLISH-ENGLISH BILINGUAL

CHILDREN, THEIR PARENTS AND SCHOOLS

Table 2

\section{Case 1: Scale comparisons}

\begin{tabular}{|l|l|c|c|c|}
\hline Scale comparisons & Difference & Significant & $\begin{array}{l}\% \text { of sample } \\
\text { with this } \\
\text { difference }\end{array}$ \\
\hline $\begin{array}{l}\text { Listening } \\
\text { comprehension }\end{array}$ & Orale expression & 13 & $\mathrm{Y}$ & $25 \%$ \\
\hline $\begin{array}{l}\text { Listening } \\
\text { comprehension }\end{array}$ & $\begin{array}{l}\text { Reading } \\
\text { comprehension }\end{array}$ & 7 & $\mathrm{~N}$ & \\
\hline $\begin{array}{l}\text { Listening } \\
\text { comprehension }\end{array}$ & $\begin{array}{l}\text { Written } \\
\text { expression }\end{array}$ & 45 & $\mathrm{Y}$ & Less than $1 \%$ \\
\hline Oral expression & $\begin{array}{l}\text { Reading } \\
\text { comprehension }\end{array}$ & 20 & $\mathrm{Y}$ & $10-15 \%$ \\
\hline Oral expression & $\begin{array}{l}\text { Written } \\
\text { expression }\end{array}$ & 58 & $\mathrm{Y}$ & Less than $1 \%$ \\
\hline $\begin{array}{l}\text { Written } \\
\text { expression }\end{array}$ & $\begin{array}{l}\text { Reading } \\
\text { comprehension }\end{array}$ & 38 & $\mathrm{~N}$ & Less than $1 \%$ \\
\hline
\end{tabular}

Table 3

Case 1: Composite scores

\begin{tabular}{|l|c|c|c|c|l|}
\hline Composite & $\begin{array}{c}\text { Sum of } \\
\text { standard } \\
\text { scores }\end{array}$ & $\begin{array}{c}\text { Standard } \\
\text { score } \\
\text { Age }\end{array}$ & $\begin{array}{c}\text { Confidence } \\
\text { interval } \\
\mathbf{9 5 \%}\end{array}$ & $\begin{array}{c}\text { Percentile } \\
\text { rank }\end{array}$ & Description \\
\hline $\begin{array}{l}\text { Oral } \\
\text { language }\end{array}$ & 171 & 84 & $79-89$ & 14 & $\begin{array}{l}\text { Below } \\
\text { average } \\
\text { (slightly) }\end{array}$ \\
\hline $\begin{array}{l}\text { Written } \\
\text { language }\end{array}$ & 236 & 120 & $116-124$ & 91 & $\begin{array}{l}\text { Above } \\
\text { average }\end{array}$ \\
\hline $\begin{array}{l}\text { Receptive } \\
\text { language } \\
\text { (LC+RC) }\end{array}$ & 191 & 94 & $90-98$ & 34 & Average \\
\hline $\begin{array}{l}\text { Expressive } \\
\text { language } \\
\text { (OE + WE) }\end{array}$ & 216 & 109 & $104-114$ & 73 & Average \\
\hline $\begin{array}{l}\text { Overall } \\
\text { language }\end{array}$ & 407 & 102 & $99-105$ & 55 & Average \\
\hline
\end{tabular}




\section{Discussion of the scores}

On the listening comprehension (LC) scale, Kamila obtained a standard score of 94 , with a percentile rank of 30 . This indicates that this score is within an average range ( 1 standard deviation above and below 100 within the 85115 range) when compared to the scores of her same-age peers. Her performance was higher than $30 \%$ of other children her age, and the test-age equivalent showed that she was performing on listening comprehension in a way that an average 11 year 3 months child would. On the Oral Expression (OE) scale, she obtained a below average score of 79 , with a percentile rank of 8 . This indicates that she was performing better than $8 \%$ of other children her age and in a way that an average 10 year 3 months child would. She scored 99 on the Reading Comprehension (RC) scale, with a percentile rank of 47. This an average score, and her performance was higher than $47 \%$ of other children her age. The test-age equivalent showed that she was performing on the reading comprehension in a way that an average 13 year 4 months child would. Kamila obtained a standard score of 137 on the Written Expression (WE) scale with a percentile rank of 99 . This indicated a very superior score when compared to the scores of her same-age peers. Her performance was higher than $99 \%$ of other children of this age, and the test-age equivalent showed that she was performing on written expression in a way that an average 21 years 11 months young adult would. This score by far exceeded all other scores and is particularly rare within a normal population of children this age (less than $2.2 \%$ ).

\section{Overall discussion of case 1}

OWLS-II revealed a large gap between oral expression and written expression (58 standard points). While the gap is large, it is unlikely to be a sign of any deficits, especially as other scores were within average range. It is not uncommon for sequential bilinguals, in whom spoken language may develop later than listening and reading comprehension. Moreover, many sequential 
bilinguals find it easier to express their ideas in writing than orally - this is because while writing, they have more time to formulate their thoughts and pay attention to grammar, style, form and spelling.

The danger, however, is that oral language is something that teachers, peers and other people with whom the child interacts notice first; therefore, they may be inclined to make the overall judgement of an individual's cognitive ability based on the oral proficiency. While this young teenager made several grammar and other mistakes in her speech, it was obvious that it was not because she did not have the knowledge and ability to formulate her thoughts well in English. To the contrary, she achieved a strikingly high score on the written expression scale, even though writing is the most complex and sophisticated skill that language learners have to develop, and many children achieve their lowest scores on the written expression scale.

Unfortunately, it seems that the large gap between oral and written expression significantly affected this teenage girl's confidence and self-esteem. She reacted with withdrawal and extreme shyness and refused to communicate with other children at school, which further thwarted her chances of practicing oral expression. Keeping exchanges within the classroom to the bare required minimum, the girl also remained to be largely invisible to her teachers, who were not only unaware of her psychological issues and behavioural problems, but also her unique talents (writing) and overall high intellectual potential and ability.

\section{Case study 2 - Lila}

The child in the centre of this case study is a young girl ( 6.2 years at the time of assessment) who was born in the UK. She is an only child, being raised in a Polish-English speaking family (Polish mother, English step-father). The mother reported that the child was initially introduced to Polish only (in her first 8 months of life) but then went to English nursery; and soon after, an English 
speaking step-father joined the family. The mother tried to maintain Polish, but she reported that it was becoming more and more difficult, and English was gradually becoming more dominant. The mother perceived the child as having English language dominancy, while Polish was being developed. She tried to communicate with the child predominantly in Polish, while the step-father used English only. In all family interactions, inevitably, English was dominant.

The mother perceived the child as coping very well with school, on target with everything, making a good effort and being slightly above average in comparison to other children. When Lila was in her year 1 (5 years old), the family moved and she went to a new school. The mother reported that she gradually became concerned with the school and the attitude displayed by Lila's classroom teacher. She recalled the teacher making assumptions about the child's background (assuming she was being raised in a Polish migrant family and that Polish was her dominant language) and making comments that "bilingual children will always lag behind." The mother became aware that the child was being perceived as not being able to achieve (allegedly due to dual language status) and was put in the bottom sets. The mother tried to reason with the teacher, but this had little impact on the child's position within the new classroom.

This continued for approximately 3 months, at which point the mother received an Individual Educational Plan (IEP) in which the classroom teacher identified Lila as having some learning difficulties ("problems with cognition and learning"). The overall aims were "to improve the reading age" and "to improve unaided learning skills." The alleged difficulties were reported to be related to the child's [assumed] bilingualism. The child was then 5.7 years old, and her reading age, comprehension age and spelling age were all on target at 5 years 7 months. The mother, surprised with the teachers' perception that the child had [alleged] special educational needs, requested re-assessment. The child was reassessed by the SENco coordinator at school, and the need for IEP was reversed. The next assessment at school was conducted when Lila was 6.2 years (end of year 1 ). Just five months after the initial report of special educational needs, the child was reported to be functioning at the following levels: 
- $\quad$ Reading age: 7.0 years

- Comprehension age: 7.3 years

- $\quad$ Spelling age: 5.10 years

This reflected more closely the mother's observation of the child's abilities. The mother perceived the child as doing well and above her age in terms of reading, comprehension and mathematics and slightly below average with spelling. The mother observed that while the child could learn to spell simple words, she often forgot the spelling after a few weeks and made mistakes in the words which appeared to have been secured before.

The school refused to take part in the study, and consequently, no further data from the teacher was obtained. Despite this, we decided to include this case study, as it highlights how some myths about bilingualism may be still alive among some teachers and how this can negatively impact on the child's development. Should the parent not have intervened and signed the paperwork for the IEP, the child could have gone through the system with the label of SEN and remain in the bottom sets. The mother reported that the relationship with the school remains strained, and she decided to keep the child there only because Lila is settled and has close friends; and her mother did not want to disrupt this with yet another move. The mother is heavily involved in the child's education, both in English and Polish, and believes that the progress the child makes is the result of this. Assessment conducted with the use of OWLS-II further illuminated Lila's language development.

Table 4

\section{Case study 2: Standard Scores}

\begin{tabular}{|c|c|c|c|}
\hline $\begin{array}{c}\text { Listening } \\
\text { comprehension }\end{array}$ & Oral expression & $\begin{array}{c}\text { Reading } \\
\text { comprehension }\end{array}$ & $\begin{array}{c}\text { Written } \\
\text { expression }\end{array}$ \\
\hline 100 & 118 & 116 & 102 \\
\hline Average & Above average & Above average & Average \\
\hline
\end{tabular}




\section{Case 2: scale comparisons}

\begin{tabular}{|l|l|c|c|c|}
\hline \multicolumn{1}{|c|}{ Scale } & \multicolumn{1}{|c|}{ Scale comparisons } & Sifference & Significant & $\begin{array}{c}\text { \% of sample } \\
\text { with this } \\
\text { difference }\end{array}$ \\
\hline $\begin{array}{l}\text { Listening } \\
\text { comprehension }\end{array}$ & Oral expression & 18 & $\mathrm{Y}$ & $10 \%$ \\
\hline $\begin{array}{l}\text { Listening } \\
\text { comprehension }\end{array}$ & $\begin{array}{l}\text { Reading } \\
\text { comprehension }\end{array}$ & 16 & $\mathrm{Y}$ & $20-25 \%$ \\
\hline $\begin{array}{l}\text { Listening } \\
\text { comprehension }\end{array}$ & Written expression & 2 & $\mathrm{~N}$ & \\
\hline Oral expression & $\begin{array}{l}\text { Reading } \\
\text { comprehension }\end{array}$ & 2 & $\mathrm{~N}$ & \\
\hline Oral expression & Written expression & 16 & $\mathrm{Y}$ & Over $25 \%$ \\
\hline Written expression & $\begin{array}{l}\text { Reading } \\
\text { comprehension }\end{array}$ & 14 & $\mathrm{Y}$ & $20-25 \%$ \\
\hline
\end{tabular}

Table 6

\section{Case 2: Composite scores}

\begin{tabular}{|l|c|c|c|c|c|}
\hline Composite & $\begin{array}{c}\text { Sum of } \\
\text { standard } \\
\text { scores }\end{array}$ & $\begin{array}{c}\text { Standard } \\
\text { score } \\
\text { Age }\end{array}$ & $\begin{array}{c}\text { Confidence } \\
\text { interval } \\
\mathbf{9 5 \%}\end{array}$ & $\begin{array}{c}\text { Percentile } \\
\text { rank }\end{array}$ & Description \\
\hline $\begin{array}{l}\text { Oral } \\
\text { language }\end{array}$ & 218 & 108 & $103-113$ & 70 & Average \\
\hline $\begin{array}{l}\text { Written } \\
\text { language }\end{array}$ & 218 & 110 & $106-114$ & 75 & Average \\
\hline $\begin{array}{l}\text { Receptive } \\
\text { language }\end{array}$ & 216 & 108 & $104-122$ & 70 & Average \\
\hline $\begin{array}{l}\text { Expressive } \\
\text { language }\end{array}$ & 220 & 111 & $106-116$ & 77 & Average \\
\hline $\begin{array}{l}\text { Overall } \\
\text { language }\end{array}$ & 436 & 110 & $107-113$ & 75 & Average \\
\hline
\end{tabular}

\section{Discussion of the scores}

On the listening comprehension (LC) scale of the OWLS-II, Lila obtained a standard score of 100 , with a percentile rank of 50 . This indicates that this score is within an average range when compared to the scores of her same-age peers. Her performance was higher than $50 \%$ of other children her age. Lila obtained a 
standard score of 118 on the Oral Expression (OE) scale, with a percentile rank of 89. This indicates that her score is above average when compared to the scores of her same-age peers (higher than $89 \%$ of other children her age), and the test-age equivalent showed that Lila was performing on the oral expression in a way that an average 7 year 10 months child would. Moreover, the required ceiling of getting 4 consecutive answers was not reached, as Lila continued answering questions designed for children of 11-13 years when the time was over (she had an extra curriculum activity to attend). Therefore, it may be the case that Lila would be able to answer more questions before she reached the limit of 4 incorrect answers given consecutively. She obtained a standard score of 116 on the Reading Comprehension (RC) scale, with a percentile rank of 86 . This is an above average score when compared to the scores of her same-age peers (higher than $86 \%$ of other children her age), and the test-age equivalent showed that Lila was performing on reading comprehension in a way that an average 7 year 2 months child would. She obtained a standard score of 102 on the Written Expression (WE) scale, with a percentile rank of 55. This indicates an average score when compared to the scores of her same-age peers. Her performance was higher than $55 \%$ of other children of her age, and the test-age equivalent showed that Lila was performing on written expression in a way that an average 5 years 7 months child would. This is below her true age but within a normal range for her peers.

\section{Overall discussion of case 2}

Overall, Lila functioned on an average/upper average level of language development. As can be seen in Table 4, Lila's strongest points are her oral expression and reading comprehension (above average, placing her in the top $80^{\text {th }}$ percentiles for both). All composite scores fall within the normal range. This is because a slightly lower level of ability to express herself in writing is compensated by a much higher level of oral expression, and similarly, poorer listening skills are compensated by better reading comprehension. 
This seems to be a natural pattern for many young children who have only begun to learn to write. As can be seen in Table 5, over $25 \%$ of children Lila's age have a substantial difference in the level of their functioning in oral and written expression. In conclusion, at odds with the initial teacher's perception, there are no significant language delays and no reasons for concern in terms of language development.

\section{Case study 3 - Marek}

The child in the centre of this case study is a boy ( 9.8 years at the time of assessment) born in the UK into a Polish-Irish family of seven. The boy is functionally bilingual, with English being more dominant and communicative Polish. The mother and other siblings speak Polish to each other, and maintaining Polish is of particular importance to the mother. The mother reported many of the child's difficulties, as well as her efforts in ensuring that the school takes her concerns on-board and provides the required support. She recalled having to provide arguments in her attempt to convince the school that her son's bilingualism is not an issue and that keeping Polish was in fact beneficial. The child was recently diagnosed with ADHD and Asperger's syndrome, and there are also signs of dyspraxia. The mother reported that she had to fight for this and take the child for a comprehensive assessment and diagnosis to a neuropsychologist in Poland, as her concerns were "fobbed off" here, and she felt she was not getting anywhere in terms of obtaining a clear diagnosis and recommendations. Following this, she received a statement of SEN.

The classroom teacher agreed that the child's dominant language was English, but he was also 'pretty fluent' in Polish. In terms of his academic performance, Marek was perceived to be performing "far below average" in literacy and numeracy and "below average" in science and history and other social studies. He "regularly goes out with the LSA for phonics and reading," and he is also "withdrawn from numeracy lessons" (presumably for extra 1:1 or small group support). For typical pupils of the same age, Marek was reported to 
work "much less," to behave "somewhat less" appropriately, to learn "somewhat less" and also to be 'somewhat less' happy. The teacher reported several concerns, among them the fact that the homework was "hardly ever completed," "he is very rarely read with at home," and "he is very well supported and cared for at school but a lack of support from home has hindered potential progress." Among other noted behaviour problems (which can mainly be associated with ADHD and social issues which may be linked to Asperger's syndrome), the teacher noted that Marek often clings to adults, demands a lot of attention and is too dependent on others. She added a handwritten note in which she stated:

From conversations I've had with [...], he says he doesn't get a lot of attention at home (this is evident through the fact that no-one sits with him to help him complete his homework or read with him). I think this is why he craves attention of adults from school.

In regards to the good points, the teacher observed that Marek was "very enthusiastic about learning," "keen to show the class interesting books/objects he has found" and that "he is a friendly and affectionate little boy (most of the time!)."

From a conversation with the mother, it transpired that she was disappointed with the school's efforts to cater for her son's specific educational needs and expected that much more should be done. She was proactive in obtaining a more conclusive diagnosis and recommendations for her son and spoke of very difficult family circumstances, which meant the family could not dedicate as much time as they wanted to support Marek (as another family member was in the centre of attention at that time) and was bitter about the lack of understanding and support from school.

Assessment conducted with the use of OWLS-II further confirmed Marek's noted language development delays. 


\section{Case 3: Standard scores}

\begin{tabular}{|c|c|c|c|}
\hline $\begin{array}{c}\text { Listening } \\
\text { comprehension }\end{array}$ & Oral expression & $\begin{array}{c}\text { Reading } \\
\text { comprehension }\end{array}$ & $\begin{array}{c}\text { Written } \\
\text { expression }\end{array}$ \\
\hline $\mathbf{8 1}$ & $\mathbf{8 4}$ & $\mathbf{8 3}$ & $\mathbf{7 5}$ \\
\hline Below Average & Below average & Below average & Below Average \\
\hline
\end{tabular}

Table 8

\section{Case 3: Scale comparisons}

\begin{tabular}{|l|l|c|c|c|}
\hline \multicolumn{5}{|c|}{ Scale comparisons } \\
\hline \multicolumn{1}{|c|}{ Scale } & Difference & significant & $\begin{array}{c}\text { \% of sample } \\
\text { with this } \\
\text { difference }\end{array}$ \\
\hline $\begin{array}{l}\text { Listening } \\
\text { comprehension }\end{array}$ & Oral expression & 3 & $\mathrm{~N}$ & Over 25\% \\
\hline $\begin{array}{l}\text { Listening } \\
\text { comprehension }\end{array}$ & $\begin{array}{l}\text { Reading } \\
\text { comprehension }\end{array}$ & 10 & $\mathrm{Y}$ & $\mathrm{N}$ \\
\hline $\begin{array}{l}\text { Listening } \\
\text { comprehension }\end{array}$ & $\begin{array}{l}\text { Written } \\
\text { expression }\end{array}$ & 2 & $\mathrm{~N}$ & \\
\hline Oral expression & $\begin{array}{l}\text { Reading } \\
\text { comprehension }\end{array}$ & 1 & $\mathrm{Y}$ & Over 25\% \\
\hline Oral expression & $\begin{array}{l}\text { Written } \\
\text { expression }\end{array}$ & 9 & $\mathrm{Y}$ & Over 25\% \\
\hline $\begin{array}{l}\text { Written } \\
\text { expression }\end{array}$ & $\begin{array}{l}\text { Reading } \\
\text { comprehension }\end{array}$ & 8 & & \\
\hline
\end{tabular}

Table 9

Case 3: Composite scores

\begin{tabular}{|l|c|c|c|c|c|}
\hline Composite & $\begin{array}{c}\text { Sum of } \\
\text { standard } \\
\text { scores }\end{array}$ & $\begin{array}{c}\text { Standard } \\
\text { score } \\
\text { Age }\end{array}$ & $\begin{array}{c}\text { Confidence } \\
\text { interval } \\
\mathbf{9 5 \%}\end{array}$ & $\begin{array}{c}\text { Percentile } \\
\text { rank }\end{array}$ & Description \\
\hline $\begin{array}{l}\text { Oral } \\
\text { language }\end{array}$ & 165 & 81 & $76-86$ & 10 & $\begin{array}{c}\text { Below } \\
\text { average }\end{array}$ \\
\hline $\begin{array}{l}\text { Written } \\
\text { language }\end{array}$ & 158 & 79 & $75-83$ & 8 & $\begin{array}{c}\text { Below } \\
\text { average }\end{array}$ \\
\hline $\begin{array}{l}\text { Receptive } \\
\text { language }\end{array}$ & 116 & 53 & $49-57$ & 0.1 & Deficient \\
\hline $\begin{array}{l}\text { Expressive } \\
\text { language }\end{array}$ & 123 & 60 & $55-65$ & 0.4 & Deficient \\
\hline $\begin{array}{l}\text { Overall } \\
\text { language }\end{array}$ & 274 & 64 & $61-67$ & 1 & Deficient \\
\hline
\end{tabular}




\section{Discussion of the scores}

On the listening comprehension (LC) scale of the OWLS-II, Marek obtained a standard score of 82 , with a percentile rank of 10 . This is a below average score when compared to the scores of same-age peers. His performance was higher than only $10 \%$ of other children his age. He obtained a standard score of 84 on the Oral Expression (OE) scale, with a percentile rank of 14. This indicates that his score is below average and his performance was higher than only $14 \%$ of other children his age. The test-age equivalent showed that he was performing on oral expression in a way that an average 7 year 4 months child would. In terms of Reading Comprehension (RC), he obtained a standard score of 83, with a percentile rank of 13 . This indicates that his score is below average when compared to the scores of his same-age peers (higher than $13 \%$ of other children his age). The test-age equivalent showed that he was performing on the reading comprehension in a way that an average 7 year 7 months child would. On the Written Expression (WE) scale, he obtained a standard score of 75, with a percentile rank of 5 . This was his weakest score and indicated a below average score when compared to the scores of his same-age peers. His performance was higher than only $5 \%$ of other children of his age, and the test-age equivalent showed that he was performing on written expression in a way that an average 6 years 10 months child would (with a nearly 3 years delay). Completing this scale was particularly challenging, as the child struggled to focus and stay on task. He rushed through and wanted to complete the tasks without paying much attention to instructions.

\section{Overall discussion of the case 2}

Overall, Marek functions on a below average/deficit level of language development. As can be seen in Table 7, all of his scores place him in the below average category, with the written expression score being the lowest. His 
listening comprehension is currently comparable to an average child of 7 years 3 months, or nearly 2.5 years below his chronological age. His oral expression is of a similar level and comparable to an average child of 7 years 4 months. The score for reading comprehension is also similar to the first two and comparable to an average child of 7 years 7 months. His weakest point (also reported by the mother) is written expression, with the score comparable to an average child of 6 years 10 months.

The composite scores provide more detailed information about different aspects of language development. Oral language (composed of listening comprehension and oral expression) appears to be the most developed, but still below the average (average range $=85-115$ ). However, two other areas (receptive language and expressive language) are particularly weak (with only respectively 0.1 and 0.4 percentiles). This requires particular attention, as the child is performing better than respectively only $0.1 \%$ and $0.4 \%$ children in the general population. The overall language score indicates an overall language deficiency and suggests that currently, the child is performing better than only $1 \%$ of children his age in the general population.

Moreover, behavioural observations made by the assessor (psychologist) confirmed the mother's and the teacher's observations that Marek had difficulties in concentration and retention of information. The boy struggled to follow instructions, and the assessor often felt that it was not so much the lack of ability to answer some of the simpler items but the lack of attention. The boy also wanted to rush through the items and often would not listen to an instruction or read an item till the end before jumping to an answer. The instructions for OWLS-II clearly state that repetition of the instructions is not allowed, and the assessor had to repeatedly remind the boy to listen carefully, not to rush, and to pause and think. Marek was quite confident of his responses and did not attempt to self-correct or check his responses. There was no sign of anxiety, and the boy seemed not to be discouraged by the more difficult items. This is a positive sign that shows certain resiliency and confidence. However, the boy found it difficult to sit for longer stretches of time (required to complete each of the sections), and this also contributed to his tendency to rush through. 
Once he lost concentration, he would become impatient and rush through the following items, which then had a deteriorating effect on his scores.

In summary, based on the OWLS-II results, this boy is a student with a language delay that increases in significance as skills along the developmental continuum become more complex.

\section{Discussion}

In this paper, we described in detail three out of ten conducted case studies. Here, we aim to discuss some common threads across all the case studies and available literature and make some tentative observations.

Firstly, in the majority of our case studies, we saw a degree of mismatch between the teachers' and the parents' perceptions of the children (in terms of their language and overall cognitive abilities, as well as their psycho-social problems). We also evidenced some discrepancies between the teachers' perceptions of the children's language abilities and the actual scores, as measured by the OWLS-II. In some cases, these discrepancies were not substantial enough to warrant concerns. However, in others, they may have led to disastrous consequences for the child. Case study 2, for instance, evidenced how the teacher's perception of the child as having "cognitive problems" led to her placing the child in the bottom sets, drafting the IEP (which suggested removing the child from the main lessons and placing her in the "remedial" small group intervention) and attaching the label of SEN. These perceptions seem to have been based on the assumption that "bilinguals will always lag behind" - a view that subsequently lowered the teacher's expectations for that child. This was despite the fact that the teacher was in the possession of the latest child's assessment, which evidenced that the child was "on target" in each aspect and was performing appropriately for her age. The OWLS-II assessment indicated an even larger discrepancy between the teacher's perception and the child's actual 
language development (well above average on two out of four scales and average on the other two).

Case 1 and another case evidenced how teachers failed to notice children's exceptional writing abilities. In both cases, the children were judged as "average" by the teachers and "well above average" by the parents. Kamila (aged 13.7) and Anna (aged 6.1) both obtained superior scores on the OWLS-II written expression scale (137 and 133 respectively). In both cases, this was even more of an achievement for the children, as both came from Polish migrant families, and for both of them, Polish was the dominant language. In both cases, the parents pointed out their disappointment with English schools - they felt that their children were presented with tasks far below their actual cognitive levels, and as a result, the children were bored and demotivated. In Kamila's case (case 1), the large score gap between her oral and written expression may have contributed to the teacher's perception of Kamila's "averageness." Such misperceptions of bilingual pupils may limit the children's chances of moving up to higher sets and accessing "gifted and talented" programmes. They may certainly affect children's self-perception and self-esteem, demotivate them and contribute to the development of other behavioural problems (in Kamila's case, further withdrawal and psycho-social problems; in Anna's case, "misbehaving" due to boredom and lack of appropriate stimulation). As Lauchlan (2014) explains, it is important to be aware of the impact of the school not valuing the child's minority language "on the child's lower self-esteem and self-confidence, a reduced belief in the learning ability, lowered academic motivation and poorer school performance" (p. 17). We believe that teachers should be very careful in their assessment and in forming perceptions about bilingual pupils. This is confirmed by Lauchlan's (2014) warning that:

an evaluation based on the administration of the test in the child's "weaker" language may lead to an under-estimation of a child's abilities, or perhaps a misdiagnosis, and generally speaking could provide a false impression, or at least a very partial and biased profile of the capabilities of the child (p. 14). 
ON BILINGUALISM IN A (MONOLINGUAL?) ENGLISH CLASSROOM ENVIRONMENT - THE CHALLENGES FOR POLISH-ENGLISH BILINGUAL CHILDREN, THEIR PARENTS AND SCHOOLS

Furthermore, we also observed the lack of deeper understanding of bilingualism and we recorded instances of well-known myths still at play. A striking example of this was the teacher's belief that bilingualism causes cognitive delays (case 2). Two other schools advocated the view that children with SEN should abandon their mother tongue (Polish) and concentrate on one language only (English). In one case (Artur), according to the mother's account, the child "developed spoken language very late and this speech delay was initially linked with behaviour traits attributable to the Autistic spectrum" (disregarded later). The family sought the opinions of a child psychologist and health professionals' and were advised to concentrate on English language development only. "The child attended monthly speech therapy sessions at the Child Development Centre and received daily speech development support from his family. All language development activities were undertaken in English," as the mother reported. Subsequently, as the mother explained, her youngest son (unlike his other two siblings) struggled to communicate in Polish. In Marek's case (case 3), the mother had to strongly put her case for the advantages of bilingual education to the school.

In another case (Natalia), the child went through a classic "silent stage" and refused to speak at school for nearly a year. The parents did not know what to think about this and were worried that the child may have a disorder such as an Autism Spectrum Disorder (ASD). They sought the school's help and support, but the school had no advice to offer, and the family was left to their own devices.

As Lauchlan (2014) highlights, children with Autistic Spectrum Disorder are likely to have problems with language and communication. However, against the advice given by the teachers and professionals (as documented above), autistic children (as well as those with other speech difficulties) could socially and culturally benefit from bilingualism, especially when living in a dual language environment. In fact, bilingualism is reported to enhance flexibility of thinking (often impaired in ASD children, Rubinyi, 2006). 
Moreover, some teachers seemed to treat bilinguals as a homogenous group. The most common perception appeared to be that Polish-English bilinguals were sequential bilinguals with Polish as a dominant language. This perception prevailed even when the teacher was in the position of facts, as in case 2 (a child born in England, living in Polish-English family with English being a dominant language), and revealed that teachers assume that Polish-English bilingual children were mainly immigrants, often born in Poland and raised by two Polish speaking parents.

Safford and Drury (2013) highlight that, rather than being viewed as a problem, bilingualism can be seen as a pedagogic resource in the classroom. Sadly, in our cases, we only saw shallow engagement of schools with bilingualism (expressed mainly through "diversity celebrations") and the lack of deeper consideration for bilingual children's needs and talents.

Finally, several Polish parents in this study referred to their perceived lack of 'power' (expressed by the lack of sufficient language skills and knowledge and their overall underprivileged position of migrants in the host society), which put them in an inferior position in terms of negotiating support for their children in schools. Even those who, objectively speaking, held a higher socio-economic status in the society and spoke English very well, expressed their concerns and a degree of "powerlessness." Moreover, some parents expressed their disappointment or even anger with the lack of understanding and support from schools. Many of them commented on the fact that they did not know what their children were learning at school and felt they had no control over their children's education, which further caused them anxiety. As Sales et al. (2008) note, parents in the Polish education system are much more engaged in their children's learning. Moreover, "the homework system and centralised curriculum provides parents with detailed knowledge of the curriculum and of their children progress." Parents are able to monitor homework and their children's progress and to help eliminate "potential gaps in knowledge acquisition" (LopezRodriguez, 2005, p.11). This is clearly not possible in the English system. However, Polish migrants are largely unaware of such structural differences and expect the same level of "service" and education that they would receive in 
Poland (Sales et al., 2008). This developed "sense of entitlement" and high expectations of education will inevitably exert pressure on the teachers and the system.

\section{Limitations of the study, tentative recommendations and further directions}

Our study was a small-scale pilot, and we do not intend to generalise from these findings. We discovered a few areas of particular tensions or difficulties for teachers, parents and children - we believe these require further investigation and attention.

Firstly, we concluded that many teachers may be unaware of the research findings and current advice when it comes to supporting bilingual learners and that there seems to be lack of training programmes and information sharing. Therefore, the first recommendation would be to increase the training offered and perhaps (especially for schools with a higher number of Polish pupils) to consider offering a tailored programme, which could highlight some differences in Polish and English educational systems.

Similarly, Polish parents often do not have sufficient knowledge of the English system of education, and this may be a source of misunderstandings, tensions and expectations that often cannot be met by schools. We believe that offering information packs, delivering information sessions and generally increasing communication with Polish parents may help lower the anxiety and help resolve some of the issues. Sales et al. (2008) offer some examples of such successful interventions in schools in London.

Finally, we have cautioned the reader about the problems with assessment of bilingual children. These are well documented in the literature and are beyond the scope of this article. However, it is important to stress that teachers' perceptions of bilingual children's abilities may have a significant psychological impact on the children's self-esteem, self-image, motivation and 
further progress in education. Teachers should be much more careful in forming their opinions and should be aware of the risk of bias (especially in terms of judging children by their oral expression) and of the potential educational consequences for the children.

More should be done to understand the experiences and needs of PolishEnglish bilingual pupils in the UK, as this is an ever-increasing group of children. In our small sample, we identified some children with very specific needs and psychological risks, pupils whose problems seemed to be "invisible" to their teachers, as well as those whose talents and high cognitive abilities seemed not to be recognised. Although there are some data available on Polish pupils in the UK (e.g. Sales et al., 2008), they largely come from teachers or parents, and the children's side of the story should be investigated further (ideally via qualitative studies). It would also be valuable to conduct a longitudinal study to document these learners' educational journeys in order to identify protective psychological factors and successful interventions.

\section{References}

Alexander, K. L., \& Entwisle, D. R. (1996). Schools and children at risk. In A. Booth \& J. L. Dunn (Eds.), Family school links: How do they affect educational outcomes? (pp. 67-88). Hillsdale, NJ: Erlbaum.

Baker, C. (2007). A parents' and teachers' guide to bilingualism. Clevedon; UK: Multilingual Matters.

Booth, R. (2013, January 30). Polish becomes England's second language. The Guardian. Retrieved from http://www.theguardian.com/uk/2013/jan/30/polish-becomes-englandssecond-language.

Bialystok, E. (2001). Bilingualism in development: Language, literacy and cognition. Cambridge: Cambridge University Press.

Dodge K. A., Pettit, G. S., \& Bates, J. E. (1994). Socialization mediators of the relation between socioeconomic status and child conduct problems. Child Development, 65(2), 649-665. 
ON BILINGUALISM IN A (MONOLINGUAL?) ENGLISH CLASSROOM ENVIRONMENT - THE CHALLENGES FOR POLISH-ENGLISH BILINGUAL CHILDREN, THEIR PARENTS AND SCHOOLS

Eccles, J. S. (1999). The development of children ages 6-14. Future Child, 9(2), 30-44.

Eversley, J., Mehmedbogovic, D., Sanderson, A., Tinsley, T., Von Ahn, M., \& Wiggins, M., (2010). Language capital: Mapping the languages of London's schoolchildren. Reading, UK: CILT.

Hamre, B. K. \& Pianta, R. C. (2001). Early teacher-child relationships and the trajectory of children's school outcomes through eighth grade. Child Development, 72(2), 625-638.

Home Office (2006). Accession monitoring report, May 2004-June 2008 (Joint online report by Home Office, DWP, HM Revenue and Customs, ODMP). Retrieved from http://news.bbc.co.uk/1/shared/bsp/hi/pdfs/22_08_06_migrantworkers.pdf.

La Paro, K. M. \& Pianta, R. C. (2000). Predicting children's competence in the early school years: a meta-analytic review. Review of Educational Research, 70(4), 443-484.

Levine, J. (1990). Bilingual learners and the mainstream curriculum. Basingstoke, UK: Falmer Press.

McCulloch, A., Wiggins, R. D., Joshi, H. E., \& Sachdev, D. (2000). Internalizing and externalizing children's behaviour problems in Britain and the US: relationships to family resources. Children and Society, 14, 368-383.

Morokvasic, M. (2004). Settled in mobility: engendering post-wall migration in Europe. Feminist Review, 77, 7-25.

Parker, J. G., \& Asher, S. R. (1987). Peer acceptance and later personal adjustment: Are low accepted children "at risk"? Psychological Bulletin, 102, 357-389.

Portes, A., \& Hao, L. E. (1998). Pluribus unum: Bilingualism and loss of language in the second generation. Sociology of Education, 71(4), 269-294.

Pollard, N., Latorre, M., \& Sriskandarajah, D. (2008). Floodgates or turnstiles? Post-EU enlargement migration flows to (and from) the UK. London: IPPR. Rawlinson, K. (2013, January 30). Polish is second most spoken language in England.

The

Independent.

Retrieved

from 
http://www.independent.co.uk/news/uk/home-news/polish-is-secondmost-spoken-language-in-england-as-census-reveals-140000-residentscannot-speak-english-at-all-8472447.html

Rose, S. L., Rose, S. A., \& Feldman, J. F. (1989). Stability of behavior problems in very young children. Development and Psychopathology, 1, 5-19.

Rumbaut, R. G. (1994). The crucible within: Ethnic identity, self-esteem and segmented assimilation among children of immigrants. International Migration Review, 28(7), 748-794.

Ryan, L., Sales, R., Tilki, M., \& Siara, B. (2009). Family strategies and transnational migration: recent Polish migrants in London. Journal of Ethnic and Migration Studies, 35(1), 61-77.

Safford, K., \& Drury, R. (2012). The 'problem' of bilingual children in educational settings: Policy and research in England. Language and Education, 27(1), 70-81.

Saft, E. W., \& Pianta, R. C. (2001). Teachers' perceptions of their relationships with students: effects of child age, gender, and ethnicity of teachers and children. Journal of School Psychology, 16(2), 125-141.

Sales, R., Ryan, L., Lopez-Rodriguez, M., \& D'Angelo, A. (2008). Polish pupils in London schools: Opportunities and challenges. London: Multiverse.

Wehby, J. H., Dodge, K. A., \& Valente, E. (1993). The conduct disorders prevention research group school behavior of first grade children at risk for development of conduct problems. Behavioral Disorders, 19, 67-78.

Winsler, A., Burchinal, M. R., Tien, H., Peisner-Feinberg, E., Espinosa, L., Castro, D. C., De Feyter, J. (2014). Early development among dual language learners: The roles of language use at home, maternal immigration, country of origin, and socio-demographic variables. Early Childhood Research Quarterly, 29(4), 750-764. 


\section{Maja Anna Jankowska}

Bedfordširo universitetas, Jungtinè Karalystè;

maja.jankowska@beds.ac.uk

\section{DVIKALBYSTĖ (VIENAKALBĖJE) ANGLU KALBOS PAMOKOJE: IŠŠŪKIAI ANGLU IR LENKU KALBOMIS KALBANTIEMS VAIKAMS IR JU TĖVAMS, MOKYKLOMS}

Santrauka. Lenkija - viena iš didžiausiu naujuju Europos sajungos nariu. 2004-2008 m. lenkai sudarè gausiausia emigrantu srauta Europos Sajungoje. Šiuo metu lenku kalba yra antroji labiausiai paplitusi kalba Anglijoje ir Velse bei gimtoji kalba daugiau nei pusei milijono gyventoju. Manoma, kad Jungtinejje Karalysteje lenku ir anglu dvikalbiu vaiku skaičius ir toliau augs, o tai lemia būtinybę stebèti ir analizuoti ju poreikius. Šiame straipsnyje apibūdinama lenku emigracija bei jos pagrindiniai bruožai, padedantys geriau suprasti lenku ir anglu dvikalbiu vaiku situacija angliškoje švietimo sistemoje. Nagrinejjami iššūkiai, su kuriais susiduria lenku tautybès tèvai, ju dvikalbiai vaikai ir šiu vaiku mokytojai, dirbdami pagal angliškas vienakalbes ugdymo ir vertinimo programas, kurios atrodo gerokai pasenusios ir neatitinkančios visuomenès lūkesčiu augančios ivairovès kontekste. Siekiant atkreipti demesi i specifinius klausimus ir problemas, pateikiamos trys išsamios atvejo analizès bei atskleidžiama, kad su dvikalbyste susiję mitai vis dar gyvi; jie lemia vaiku psichosocialini vystymąsi ir elgesi. Straipsnyje pateikiamos preliminarios rekomendacijos bei aptariamos tolimesniu tyrimu kryptys.

Pagrindinès sąvokos: lenku ir anglu kalbu dvikalbiai, švietimas, kalbiniu kompetenciju vertinimas, kalbinis ir psichosocialinis vystymasis. 